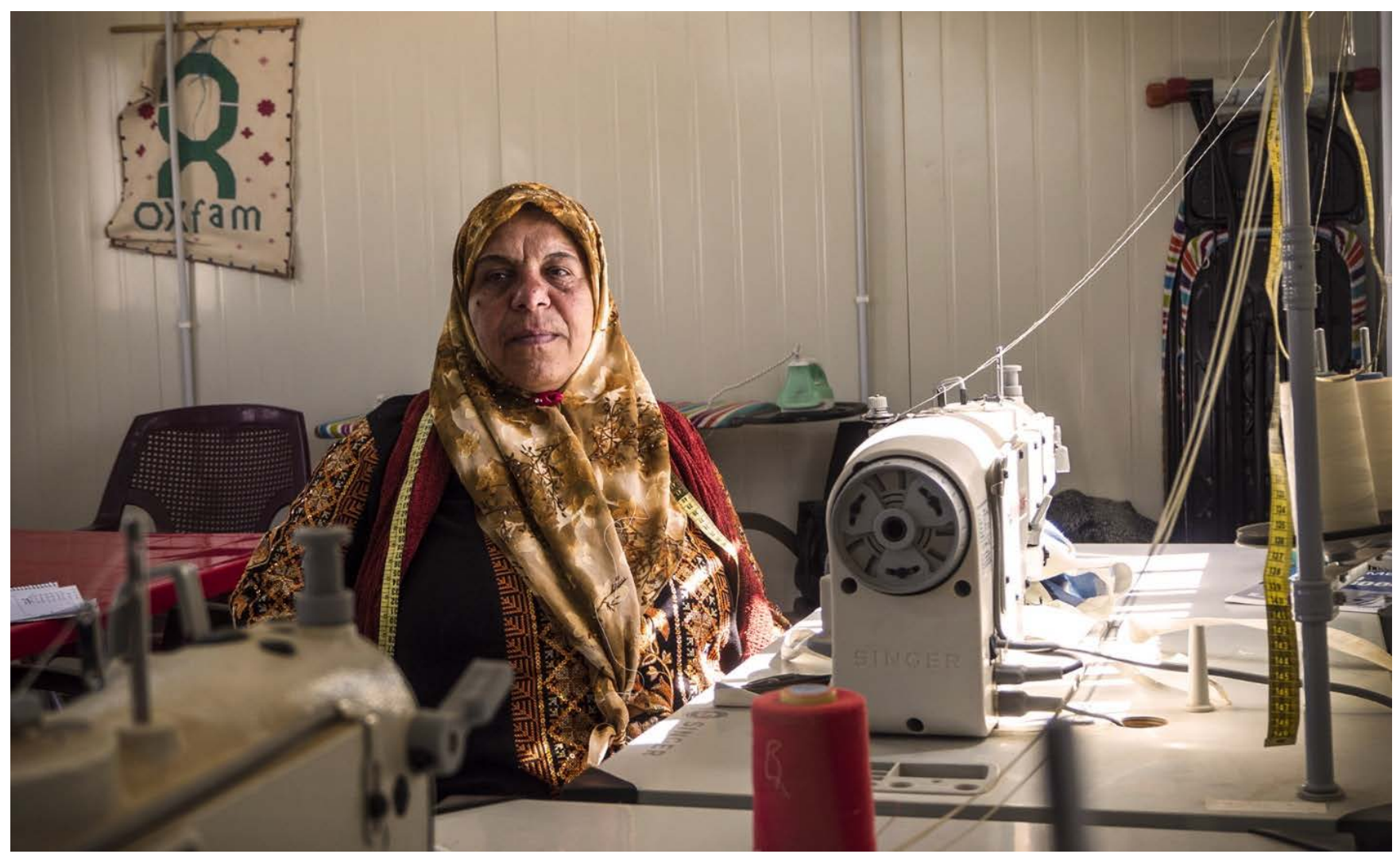

Fatima speaks to Oxfam about her skills and experience developed back in southern Syria before the outbreak of conflict. Photo: Alix Buck/Oxfam.

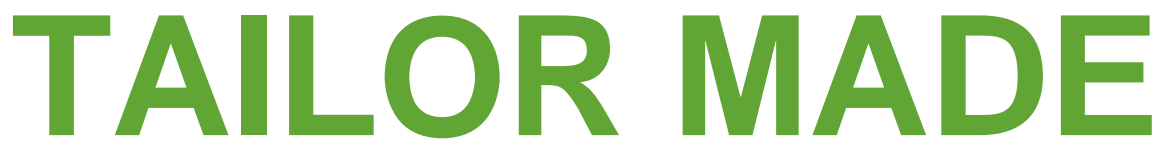

\title{
How Syrian refugee women are finding their own way to join the Jordanian economy
}

Earning an income is a struggle for the residents of Za'atari refugee camp in Jordan, and women's economic participation is extremely low. Oxfam initiated the Lel-Haya (For Life) project in Za'atari to build the capacities of Syrian refugee women, both in vocational training and soft skills. A small number of women involved in the project were subsequently employed by a garment factory in northern Jordan. This briefing note highlights these women's experiences, the challenges they have face and how they have overcome them. 
'There's a lot of work, but it's nice to be with other people. You're under pressure, so you work together and cooperate.'

- Mariam, a 26-year-old Syrian refugee, former Oxfam programme participant and current garment factory employee

Za'atari refugee camp, located in northern Jordan, is home to nearly 80,000 Syrian refugees, half of whom are women and girls. Syrian refugees are not currently returning in large numbers from Jordan to Syria due to the continuing violence and insecurity. Amidst this protracted displacement, it is essential that aid supports selfreliance.

Forty-two percent of the camp population is of working age. Those looking for employment must compete for around 5,000 cash-for-work positions in the camp. ${ }^{1}$ These short-term jobs offered by humanitarian organizations are the main form of employment in Za'atari camp, aside from informal businesses run by refugees. A reduction in the number of cash-for-work positions available - down from 7,000 openings in December 2017 - has highlighted the need for better access by camp residents to jobs in the mainstream economy.

However, under the current legal framework Syrian refugees have limited ability to independently access livelihood opportunities. This is especially true for those residing in the camp, whose options are mostly restricted to employment arranged by the United Nations High Commissioner for Refugees (UNHCR) and the International Labour Organization (ILO). Women in particular are excluded from employment opportunities and currently fill only one-third of the cash-for-work positions available.

The Government of Jordan's recent commitment to 'consider expanding the sectors and occupations open to Syrian refugees... with a particular focus on women's participation' 2 indicates that there may be developments planned on work permit policy that favour women's inclusion. The government's approach centres on formal work to enhance refugee self-reliance, one of the four objectives of the forthcoming Global Compact on Refugees. ${ }^{3}$ However, this can only be guaranteed when implemented policies are multifaceted in their approach, considering both labour market needs and gender-based challenges faced by refugee women. Within Jordan, there is an opportunity to move towards the implementation of allencompassing policies that better promote refugee women's economic independence. 
The Jordan Compact, agreed between governments attending the Supporting Syria and the Region conference in London in early 2016 , set out a plan for international cooperation to support Jordan in meeting the needs of vulnerable communities affected by the Syria crisis. ${ }^{4}$ While recognizing the important role that Jordan has played in hosting large numbers of Syrian refugees and acknowledging the negative impact on the country, the compact aims to facilitate the response to the crisis as a 'development opportunity' - including through leveraging greater international financial support and trade concessions.

In return, the Government of Jordan announced its commitment to create 200,000 job opportunities for Syrians over a three-year period. Swift action was taken to improve the system for accessing work permits including waiving fees and relaxing rules around identity documents and legal proof of entry into Jordan. However, progress has since slowed and a greater focus is placed on measuring the number of work permits issued rather than promotion of decent work for refugees. This has compromised commitments to genuine job creation and inclusive development in Jordan.

The work permit programme has had success in Za'atari camp. As of July 2018 , 10,000 work permits had been issued to refugees in the camp through the Za'atari Office for Employment, ${ }^{5}$ which is jointly run by UNHCR, ILO, the Syrian Refugee Affairs Department and the Ministry of Agriculture. However, many of the permits acquired have been 'non-employer-specific' agricultural permits that do not necessarily translate into job opportunities. Instead, these work permits are often used in an unauthorized way as entry and exit permits, exposing refugees to legal and protection risks when leaving the camp. While the current framework is meant to facilitate livelihood opportunities that eventually lead to economic independence, the process continues to be highly controlled through the centralized job centre rather than allowing for natural flows of labour into and out of the camp.

\section{JOB FAIRS TO ENCOURAGE WOMEN INTO FORMAL WORK}

Oxfam initially had difficulties in attracting women in Za'atari camp to its cash-forwork programmes. When Oxfam staff approached women to find out more about their reluctance to join, the team learned that the women did not find the work opportunities appropriate for them. They were also uncomfortable in workspaces with men. In response to these concerns, Oxfam introduced the Lel-Haya project. This sought to create a women-friendly workspace, hiring only Syrian refugee women as seamstresses to transform old UNHCR tents into fashionable tote bags. The project generated interest from the ILO and UNHCR. The Za'atari Office for Employment then coordinated with a garment factory based in Irbid to organize a job fair in the camp with the aim of recruiting women from Za'atari camp, including those participating in the Lel-Haya project, into formal jobs in the factory.

The job fair took place as planned, but although women in the Lel-Haya project were all interested in the work, most ultimately did not join the employment programme. This was despite childcare incentives of 25 Jordanian dinars (approximately \$35) per 
month provided by the factory for each child under the age of four, and ILO-arranged buses to transport women from their districts to the camp main gate. Oxfam interviewed 10 women from the project to understand why many women chose not to take up this opportunity. ${ }^{6}$

The garment factory was specifically looking for women under the age of 35 , since they believe that younger women would be better suited for the job. This meant that older women were not eligible, limiting the number of women that could enrol and excluding skilled seamstresses who were willing and able to work. Distance was another major factor influencing women's decision not to enrol - the factory is about $40 \mathrm{~km}$ from the camp, which takes about an hour by road. Many women were unable to overcome the challenges associated with being far from their households for long hours. Male family members of several of the women took issue with the idea of them working outside the camp - concerns which were heightened because of the distance and the long working hours involved. Suhair told us, 'I signed up at first, but then my husband said he wouldn't allow it... [The factory] did not call me afterwards anyway. ${ }^{77}$ Oxfam found out later that this was probably due to her age, since she is 40 years old.

\section{Box 2: Fatima's need to put her skills to good use}

Fatima is 59 years old and from Dara'a, Syria. She fled to the safety of Jordan in 2013. Fatima's journey through hardship, a lack of job opportunities and associated poverty are common in Za'atari camp. Fatima, like many women in the camp, has many talents and skills yet she struggles to find work. She said, 'Maybe they won't let me work because I'm older; they worry I might get sick while I'm at work. I'm tired of sitting alone at my house. I need to work. It's sad to see my talents fade as the years go by.'

She is a skilled seamstress and joined Oxfam's Lel-Haya project, where she took the opportunity to work and produce tote bags for sale. She told Oxfam, 'I feel like I'm a captive because of my age. If women of all ages were given opportunities to work, it would help us to heal and grow after all the destruction and loss we suffered. Working with others would keep us occupied.' Ageism in the workforce excludes skilled women like Fatima who want the opportunity to earn an income, but face restrictions due to their age. To compensate for this gap in available work opportunities, there need to be more cash-for-work programmes that accommodate older women refugees.

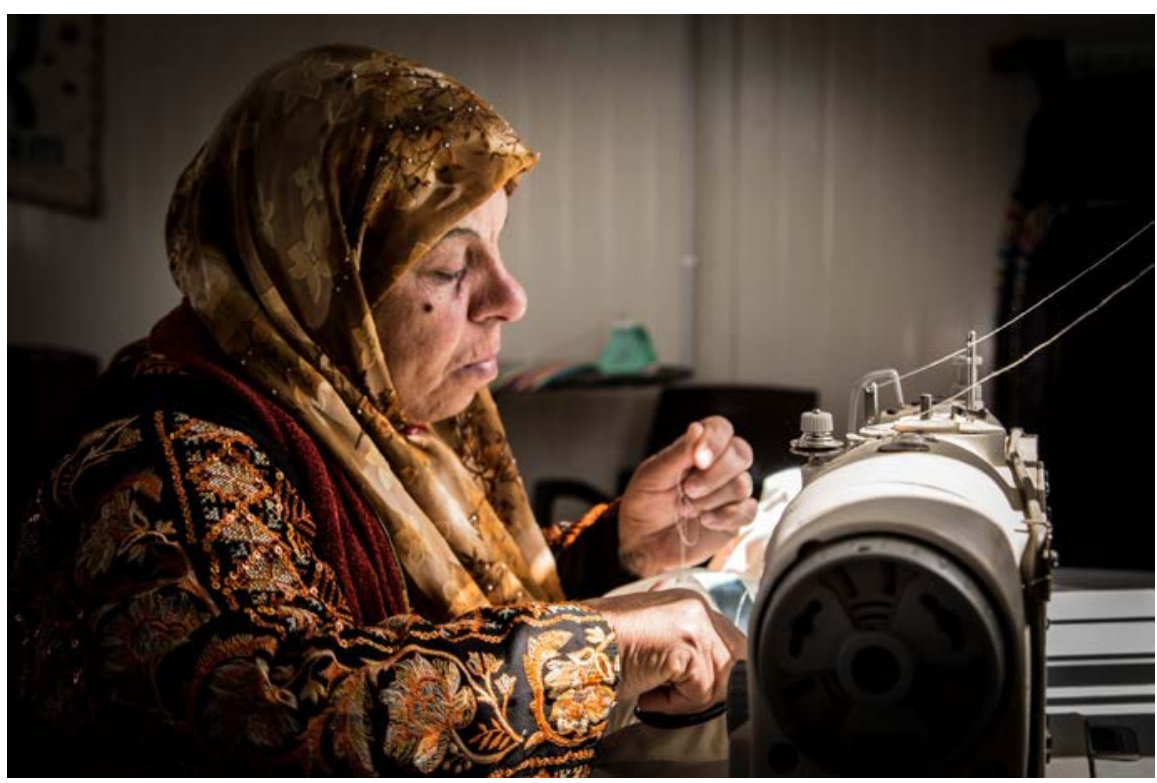

Fatima sewing bags from old refugee tents as part of an Oxfam project to support women in finding paid work. Photo: Nesma Alnsour/Oxfam. 
Women's movement when working at the factory was also restricted due to the distance from the camp. Affordable transportation options, such as public buses, are viewed as unsafe and put women at risk of harassment. Taxis are safer, but more expensive: at around 10 Jordanian dinars $(\$ 14)$, the taxi fare from the factory to the camp is unaffordable, which means the women are unable to get home easily during the day if they need to, including in an emergency. They do not have many options for childcare, so they are worried about leaving their children alone for long periods due to fears for their safety in the camp. Aziza, a mother who eventually declined to participate in the job programme, explained to Oxfam that 'in Syria, we could go out all day for hours. But here, even the smallest spark means that our houses could burn down. There is a lot of risk in being far away. ${ }^{8}$

Social networks, rumours and word of mouth negatively affected how women perceived the jobs on offer at the garment factory, and women also put the low enrolment rate down to this. Only two of the women that Oxfam interviewed previously worked at garment factories in Jordan. However, it was unanimously agreed that treatment of workers at factories was poor. Sara told us, 'We all talk to each other. We hear that the conditions at [the factory] are not very good. They treat the workers there very badly, [there is] constant criticism and orders. ${ }^{9}$ They thought that if this factory was better than they had heard, then more Syrian women would be interested in working there. Sara went on to say, 'If [the factory] manage[s] to hold on to just five Syrian women, they alone will bring 500 others. ${ }^{.10}$

Women were also concerned about missing aid distributions if they went to work in the factory. Aziza said, 'If we're away from the house all day... who is going to collect aid from the [cash distribution centre]?'11 The need to attend cash distributions acted as a disincentive to working in long-term jobs outside the camp, showing that the security of aid was prioritized over income from work.

The approach undertaken in this employment programme was driven by the aim to promote formal, long-term work that enhances self-reliance, but it failed to attract many women. For those who did enrol for the garment factory work at the job fair, their acceptance of the job was tied to the provision of safe and accessible transport. Throughout our discussions, women from the Lel-Haya project mentioned that they would be open to working in or close to the camp.

\section{EXPERIENCES OF WOMEN WHO TOOK UP JOBS}

Oxfam followed the experiences of four women - Sawsan, Heyam, Mariam and Amina (aged 20, 23, 26 and 29 respectively) ${ }^{12}$ - who enrolled at the garment factory. Through weekly interviews, the Oxfam team tracked their experiences over their first two months of work. ${ }^{13}$ None of the women had worked before coming to Jordan, and although they had worked in the Lel-Haya project, this was their first experience of being in the formal workforce. As shown below, their unique situations at home influenced their experiences of formal employment in different ways. 


\section{OPPORTUNITIES AND ADVANTAGES OF FORMAL EMPLOYMENT}

\section{Increased mobility and social interaction}

Restrictions on leaving Za'atari camp prevent normal interactions between camp residents and host communities. Working in the garment factory, which is generally considered a women-friendly workspace, gave women in the camp the opportunity to leave almost every day. Sawsan said, 'I like leaving the camp... Za'atari is so dusty. ${ }^{14}$ The opportunity to go to work with a group of other women from the camp has also fostered new social ties. This positively impacted their perceptions of work at the factory, which they found improved when they were supported by other women in a similar position. This created a sense of solidarity when the work was stressful. Mariam said, 'There's a lot of work, but it's nice to be with other people. You're under pressure, so you work together and cooperate. ${ }^{15}$ Working at the factory was an opportunity to make new friends, both with other Syrians and with Jordanians. The bonds they formed made their experiences at the factory more than just a job - it was an opportunity to leave their homes and meet new people. Amina told us, 'It's my first time leaving the house, honestly... It's a nice feeling. ${ }^{16}$

\section{Long-term skills and career development}

Refugee women working in the garment factory are motivated by the opportunity to build their capacities and learn vocational skills. They understand that gaining and perfecting these skills will not only help them to advance in the workplace, but can benefit them in all aspects of their lives. As Sawsan put it, 'Learning to sew is an investment for the future. The factory [job] won't be around forever, but I can always use sewing around my house, for my kids, maybe even make some money from sewing on my own. ${ }^{17}$ The women are motivated not only by income but by the desire to perform well. They take pride in the work they contribute to at the factory. Mariam told us, 'We want Arab production to be good. We want the work to be high quality. Some of the clothes that come out of the factory are so beautiful; they're great pieces of work and we want to maintain that standard. ${ }^{18}$ The development of their skills over time, contributing to good performance on the job, has increased their motivation to work at the factory.

\section{Employment benefits}

Syrian women in the formal workforce are eligible for benefits that they would not receive in an informal work setting. Cash-for-work program benefits are limited as well. For instance, maternity benefits, as per Za'atari Camp cash-for-work standard operating procedures, are limited to a 40 -day break, without pay. ${ }^{19}$ Acquiring a formal manufacturing job, however, means women can access social security and other benefits, including paid maternity leave. Sawsan, one of the women engaged by Oxfam in the study, is pregnant and will be granted 70 days of paid maternity leave from the factory, as stipulated by Jordanian labour law. The variety of jobs available at garment factories also allow for greater flexibility for pregnant women, who can be given lighter tasks. Sawsan told us, 'They pay attention to these things and have been taking care of me. They say that my workload should stay light and 
that I shouldn't work too hard. ${ }^{20}$ The staff help her when necessary, making her workload easier to manage.

\section{CHALLENGES AND DRAWBACKS OF FORMAL EMPLOYMENT}

\section{Transport and working hours}

Workdays at the factory are considerably lengthened by transport times. Women work standard eight-hour days, but this increases when factoring in a total of two hours of travel to and from the factory. The journey was made longer when factory staff added new bus stops along the way to accommodate other workers. One woman reported that her parents complain about her increasingly late return from work. Mariam said, 'The bus route keeps getting longer and more tiring. My parents are starting to get upset about this and I think they might start to take issue with the lateness. ${ }^{21}$ Social norms dictate that women's work is often considered unnecessary; in Mariam's case it is not vital to meet her family's needs. Because their work is considered non-essential, working outside the camp is only acceptable for women under certain conditions. Late returns are only seen as acceptable for male family members, since they are expected to work. Mariam has been able to keep working because she has started calling her parents on the way home.

Figure 1: The average working day for Syrian refugee women from Za'atari camp

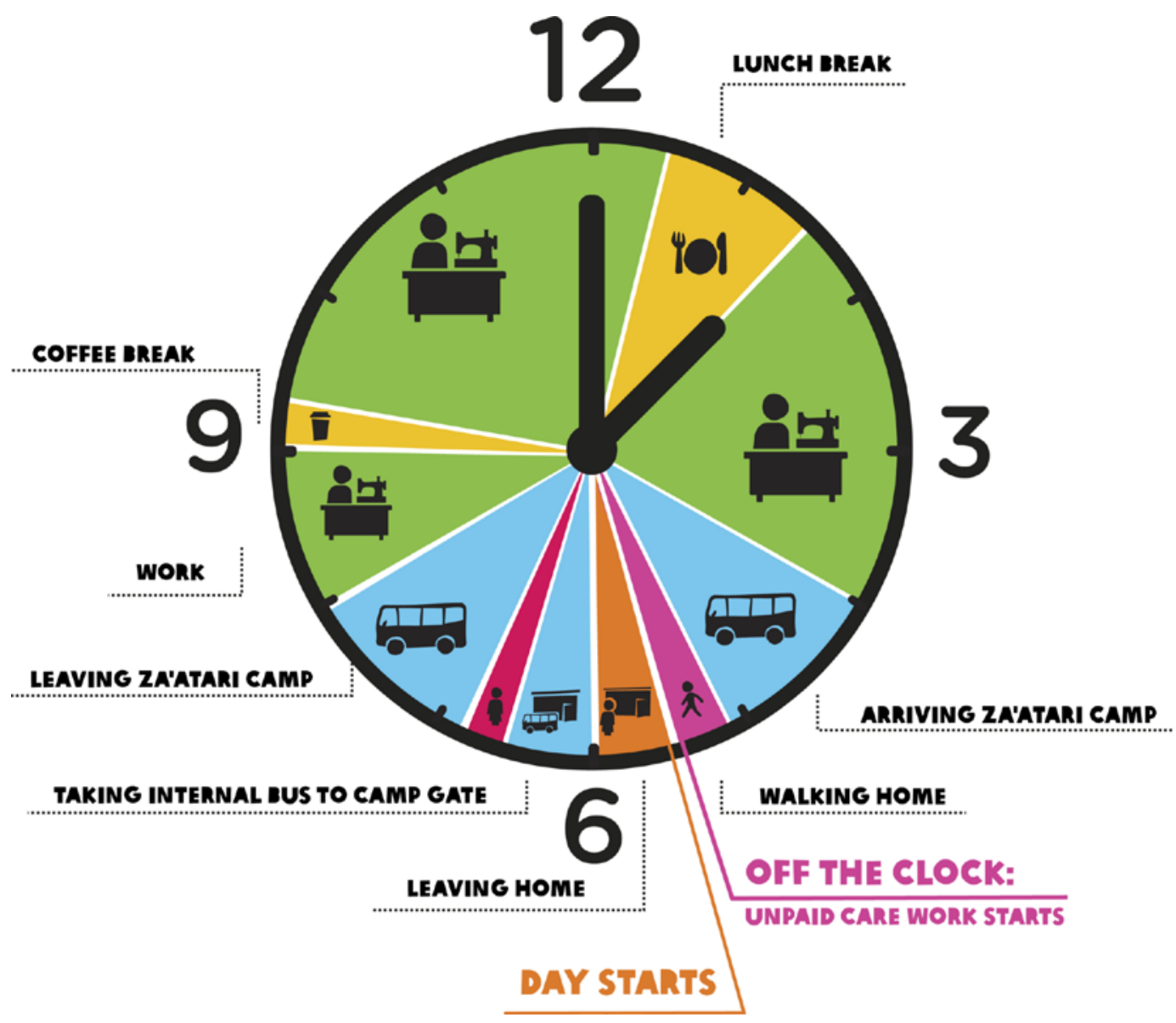


As previously mentioned, the working hours also present challenges for women who are the designated recipients of cash aid from the Za'atari camp cash distribution centre. While the centre is open until $6 \mathrm{pm}$, unreliable return times mean that many of the women choose to compromise their jobs by staying at home on cash collection days, rather than risk missing the collection. According to an HR officer at the factory, these regular absences have been a problem. Asking someone else in the household to attend the collection in their place has not been an option for the women; a UNHCR associate reports that responsibility for collection can only be designated to someone else in the household in rare cases, for example if the usual recipient is elderly, pregnant or has another vulnerability. It is daunting for refugees to give up on aid distributions in order to take up formal work under the permit system. ${ }^{22}$

\section{Childcare and family responsibilities}

Women who decided not to enrol at the factory complained that because they had older children they were ineligible for the childcare allowance that women with younger children would receive. The women who did take on the work (our cohort of interviewees) had only young children, or no children. This, along with the restriction on age, shows a bias towards younger women workers by the factory. According to an associate at UNHCR, older women are more likely to have children in different age groups and to experience difficulties in finding childminders or childcare facilities, especially those that will accommodate different ages. This can result in negative coping mechanisms where they depend on their older daughters, often in their early teens, to look after younger siblings. As a result, childcare responsibility is not redistributed from women to men and other support structures in the camp, but to other younger women, possibly of school age, illustrating the intergenerational impact of gendered unpaid care work.

Amina, who has two children aged under four, leaves them with an informal childminder during the day and pays her all the childcare allowance she receives from the factory. Sawsan leaves her children with her in-laws. These women are able to access full-time jobs outside the camp by benefiting from their existing informal networks. Other Syrian women who cited childcare as an obstacle to working made no mention of these networks, suggesting that they are unable to access them.

However, even those who do benefit from strong social ties face challenges related to childcare. For example, Amina has experienced problems because of her inconsistent arrival time from work. Since her childcare is done through a business arrangement and not by a voluntary family member, there is little flexibility around pick-up times. Although women have faced challenges with using the childcare allowance, this factory is one of very few employers in Jordan that has a scheme for childcare provision at all, despite the labour code mandating the provision of childcare facilities. ${ }^{23}$ This suggests that improving the implementation of this law is crucial for the employment of Syrian women in Jordan; otherwise women's employment throughout Jordan will be even more difficult to achieve than it was at this particular factory. 


\section{CASH-FOR-WORK IN CAMPS VERSUS FORMAL EMPLOYMENT IN HOST COMMUNITIES}

\section{OPPORTUNITIES IN THE CAMP}

For women in the camp, cash-for-work programmes provide an alternative to offcamp employment. However, as described above, such opportunities are limited and information regarding such job vacancies fails to reach many of the women who would be interested in them. Even though the cohort of Syrian women who took on jobs at the garment factory were participants in Oxfam's Lel-Haya project, they said that they were unaware of how to find cash-for-work in the camp. They had only heard of the Lel-Haya opportunity through word of mouth, particularly from neighbours and friends. Many women in the camp do not have opportunities to leave their homes and do not spend much time at community centres, where job vacancies are posted.

\section{THE FORMAL WORK TRADE-OFF}

As shown above, formal work opportunities do exist for women living in the camps, but involve a trade-off: consistency versus proximity and convenience. Cash-for-work opportunities in the camp, while close to refugees' homes, are all short term. Unlike cash-for-work positions, formal work presents an opportunity for a consistent, reliable income for an extended period.

The location of the camp - or perhaps the locations of private sector opportunities in north Jordan - puts women camp residents at a disadvantage in Jordan's job market. Reem, who was in Oxfam's Lel-Haya project, worked at the garment factory for only one day before quitting. She said she was unable to continue working because she had six school-age children. Muna, who worked at a factory for just four months before quitting, said the main reason she left was that she was the sole carer for her elderly mother and young daughter. It was difficult being away from them for so long every day, and this was exacerbated by the additional two to three hours spent travelling. She told us, 'The reason we liked the idea of working at a factory was that the job was permanent... Working in the camp is nice, but it is unstable since you can't have the same job for more than a few months. ${ }^{24}$

Another option for formal work for women living in camps is acquiring a nonemployer-specific work permit through the Za'atari Office for Employment, although women in the camps have not generally been taking this option. Women are put off by a perception of the bureaucracy involved in accessing host communities rather than having free movement; at the same time, they have concerns about moving around unprotected beyond the camp, as it is felt to be unsafe. To date, most opportunities offered by the camp office for women's employment have been in distantly located factories. The low enrolment of women in these factories, and the difficulties associated with leaving the camp, show the need to increase the flow of 
labour into and out of the camp to better foster long-term economic opportunities for refugees.

\section{CONCLUSION AND RECOMMENDATIONS}

Women who accepted a job at the garment factory generally reported positive experiences of working there, and expressed interest in staying long term. Although there was a low uptake, the experiences of those who were able to benefit from the factory work show that such opportunities should continue to be offered for those who are willing and able to overcome the challenges associated with them. Positive perceptions about the work may have a multiplier effect, as the few who report good experiences pass this on to their friends and relatives. However, these women do not represent the majority of women in the camp. While they have found their own solutions to common challenges to taking on formal work in Jordan, the genderbased barriers that prevent the majority of Syrian refugee women from entering the workforce remain.

As this example has shown, formal work offers women the opportunity to develop a trade and maintain a long-term job, in theory offering a much more viable and sustainable option for Syrian women's livelihoods. This is especially the case for camp residents, who cannot access informal work as easily as refugees in host communities. Facilitating mobility for camp residents and loosening restrictions on entry and exit could also present development opportunities for the surrounding areas, as Syrians would be able to engage in the economy more naturally, whether by finding employment opportunities or running small businesses.

Moving forward, greater consideration needs to be given to sustainable approaches in livelihood policy for refugees in camps. In Jordan, Syrian refugee camp residents account for some 125,000 individuals (between Za'atari and Azraq camps). Under the current legal framework, their ability to independently access livelihood opportunities and engage with the host community is very limited, and their employment heavily controlled.

While job fairs are held to match women with long-term employment, the method by which they find and access these jobs is through subsidized incentives negotiated by the ILO, meaning that none of these employment opportunities would exist in the market without these interventions. As with cash-for-work positions, such jobs are tied to project funding, compromising their sustainability. Employment and permits still need to be arranged through UNHCR and the ILO, reducing refugee autonomy in this process. A shift in the approach to refugee livelihoods that is ultimately meant to enhance self-reliance is contradicted and undermined by the closed nature of camps. Oxfam urges key stakeholders, including national and local authorities, to consider the following recommendations when shaping work opportunities for Syrian refugee women. 


\section{HUMANITARIAN AND DEVELOPMENT ORGANIZATIONS SHOULD:}

\section{Integrate social dynamics around women's economic participation into their programming.}

Within households, decisions on women's work have to be approved by male relatives. This has been a major obstacle to women joining the labour force. There needs to be greater acceptance of and support to women's right to access work, and the benefits thereof. Programmes should identify and support the diverse range of ways in which women negotiate with their families and communities, and navigate the employment and assistance systems. This could also include addressing male concern and potential resistance to women's right to work. Men of different generations and groups should be targeted by awareness-raising campaigns dedicated to advocating for Syrian women working and other opportunities for building alternative and positive role models.

\section{THE GOVERNMENT OF JORDAN SHOULD:}

\section{Improve the mobility of Syrian refugees in camps.}

The process of applying for and acquiring leave permits and work permits in the camp undermines Syrian refugees' ability to find work. The current system puts refugees at risk as it creates an incentive to acquire a non-employer-specific permit and use it illegally, i.e. for the sole purpose of entry and exit from the camp, or to find work in other sectors. Allowing free movement into and out of the camp would improve refugee interaction in surrounding communities. This would create opportunities for camp residents to form connections with Jordanians and other Syrians, building a much more sustainable foundation for refugee inclusion in the formal labour market.

\section{Ensure provision of affordable and safe public transport options for women.}

In the National Employment Strategy (2011-2020), public transport is identified as an area that requires improvement to increase women's employment, especially in rural areas. Despite this, there has not been any significant shift in transport provision that has attracted more women into work. Affordable options, such as buses, are considered unsafe and inaccessible in many areas, and safer options, such as taxis, are expensive. To include women of all income levels in Jordan's labour market, transportation challenges must be addressed by introducing costeffective, women-friendly options. 


\section{Incentivize provision of childcare facilities.}

The labour code's article on childcare provision disincentivizes the hiring of women. It stipulates provision of workplace nurseries in any facility that employs at least 20 women with a total of 10 children under the age of four. ${ }^{25}$ In practice the implementation of this law has been poor, leaving it largely ignored by employers who do not want to shoulder the cost of providing this service. It would be more effective for the private sector and the government to share the burden of childcare, with the government promoting the hiring of women by providing tax breaks or other subsidies to companies that provide nurseries.

\section{UNHCR SHOULD:}

\section{Ensure that working Syrian women can collect cash and other aid distributions.}

Distribution of cash assistance to meet refugees' needs should complement rather than hinder refugees' pursuit of job opportunities. The current cash distribution mechanism in Za'atari camp - an iris scan at the cash collection centre - creates a disincentive for refugees to work in host communities because it requires the presence of the beneficiary to collect the cash within certain hours. The distribution centre closes around 6pm, just as women return to the camp from work. For working Syrian refugee women, cash collection would be better facilitated by the adoption of mobile cash distribution, allowing greater flexibility. 
1 As of May 2018. Cash for work (CfW) is an initiative in which refugees are remunerated for supporting partner programming in the camp. As per the Cash Learning Partnership definition: 'Cash payments provided on the condition of undertaking designated work. This is generally paid according to time worked (e.g. number of days, daily rate), but may also be quantified in terms of outputs (e.g. number of items produced, cubic metres dug). CfW interventions are usually in public or community work programmes, but can also include home-based and other forms of work.' CaLP (2017) Glossary of Cash Transfer Programming. Technical Advisor Committee. Cash Learning Partnership. July 2017. http://www.cashlearning.org/resources/glossary

2 Supporting the future of Syria and the Region, Brussels II Conference - Jordan partnership paper. Paragraph 33 April 2018.

3 Self-reliance was listed as the second objective in the advance version of the Global Compact on Refugees (para. 7). Women and girls' economic empowerment is specifically mentioned in para. 75 under 'Meeting needs and supporting communities', where it states, "Measures to strengthen the agency of women and girls, to promote women's economic empowerment and to support access by women and girls to education (including secondary and tertiary education) will be fostered". http://www.unhcr.org/5b51fd587

4 Jordan Compact (2016) https://reliefweb.int/report/jordan/jordan-compact-new-holistic-approachbetween-hashemite-kingdom-jordan-and

5 UNHCR - Jordan Za'atari Camp Factsheet. July 2018. https://data2.unhcr.org/en/documents/details/64690

6 Methodology note: Oxfam held a focus group with women participating in the Lel-Haya project in February 2018. These women had the opportunity to enrol, but ultimately did not work at the factory for a number of reasons. The focus group was held with the aim of learning the reasons for not enrolling in the employment programme.

7 Focus group discussion with Lel-Haya project participants. March 2018.

$8 \mathrm{lbid}$.

9 Ibid.

10 lbid.

11 lbid.

12 Names changed to protect the women's identity.

13 Methodology note: From March to May 2018, Oxfam conducted a series of weekly telephone interviews with four women who started work at the factory. These were conducted to assess the women's attitudes about the work, work conditions, and periodic changes in their home and family situations and how this impacted their work. In April 2018, we also conducted two telephone interviews with women who previously worked at factories but ultimately left the job, to learn what motivated them to work, and what ultimately pushed them away.

14 Telephone interview with Sawsan.

15 Telephone interview with Mariam.

16 Telephone interview with Amina.

17 Telephone interview with Sawsan.

18 Telephone interview with Mariam.

19 Cash-for-Work in Za'atari Camp Standard Operating Procedures. July 2018.

20 Telephone interview with Sawsan.

21 Telephone interview with Mariam.

22 In previous research, Syrian refugees Oxfam spoke to feared that formalizing their economic activities, through accessing a work permit for instance, would lead to cuts to their humanitarian assistance or compromise potential resettlement. See ACTED, CARE, DRC, Oxfam, Save the Children (2017) Balancing the Books: including women and protecting refugees is essential to 
realizing small business growth in Jordan. LEADERS Consortium. 10 December 2017 https://www.oxfam.org/en/research/balancing-books-including-women-and-protectingrefugees-essential-realizing-small-business

23 The labour code mandates the provision of childcare facilities in companies with at least 20 women, who collectively have at least 10 children under the age of four. However, $98 \%$ of companies in Jordan are small and medium enterprises (fewer than 19 employees), meaning that the majority of employers are excluded from this law by default. Fines for failing to implement this law are low relative to the perceived cost of providing daycare, meaning that many would rather pay the fines than undertake the cost of providing childcare facilities. See Yacoub Shomali (2016) Value of daycare services in the workplace: A case study of Jordan's telecommunications sector. SADAQA, July 2016 http://www.sadaqajo.org/sites/default/files/files/DaycarePaper.pdf

24 Telephone interview with Muna.

25 Section 72, Jordan Labour Code. Law 8 of 1996.

http://www.ilo.org/dyn/natlex/docs/WEBTEXT/45676/65048/E96JOR01.htm\#c7 
This paper was written by Shaddin Almasri. Oxfam acknowledges the assistance of Soman Moodley, Nada Alsroor, Alixandra Buck and Nesma Alnsour in its production, as well as the refugee women who volunteered their time during the research process. It is part of a series of papers written to inform public debate on development and humanitarian policy issues.

The Lel-Haya project is kindly funded by the Australian Department of Foreign Affairs and Trade. The views expressed in this publication are those of Oxfam and are not necessarily the views of the Australian Government.

For further information on the issues raised in this paper please email advocacy@oxfaminternational.org

This publication is copyright but the text may be used free of charge for the purposes of advocacy, campaigning, education, and research, provided that the source is acknowledged in full. The copyright holder requests that all such use be registered with them for impact assessment purposes. For copying in any other circumstances, or for re-use in other publications, or for translation or adaptation, permission must be secured and a fee may be charged. Email policyandpractice@oxfam.org.uk

The information in this publication is correct at the time of going to press.

Published by Oxfam GB for Oxfam International under

ISBN 978-1-78748-314-9 in August 2018.

DOI: $10.21201 / 2018.3149$

Oxfam GB, Oxfam House, John Smith Drive, Cowley, Oxford, OX4 2JY, UK.

\section{OXFAM}

Oxfam is an international confederation of 20 organizations networked together in more than 90 countries, as part of a global movement for change, to build a future free from the injustice of poverty. Please write to any of the agencies for further information, or visit www.oxfam.org 